\title{
A PACKED PROGRAMME
}

\section{Dear Reader,}

I don't know about you, but I have the feeling that this year has simply flown by. It was brim full of fascinating topics for MTZ and its sister magazines, with interesting expert discussions and attractive conferences. In a year that has not been an easy one for publishers, we have nevertheless succeeded not only in keeping the ATZ/MTZ group on the right course but also - not least with Springer für Professionals - in establishing the basis for a prosperous future. All the more reason, therefore, to thank you for your loyalty towards our publications. We look forward to providing you with even more exciting topics in 2013.

Once again, our rucksack is also fully packed with conferences in 2013. The season already opens at the end of January with "Der Antrieb von morgen” [Powertrain of Tomorrow] in Wolfsburg. In midFebruary, the Stuttgart International Symposium focuses once more on automotive and engine technology. Spring and summer will see the ATZ conferences on "Werkstoffe im Automobilbau" [Materials in Automotive Engineering] in Stuttgart and "chassis.tech plus" in Munich as well as the "Automotive Acoustics Conference" in Zürich, which we would like to highly recommend as a supplement to your core field of business. And in autumn, our events follow in quick succession: the $15^{\text {th }}$ "Virtual Powertrain Creation" congress in September will bring together simulation experts, while engine experts will gather at the conference on "Ladungswechsel im Verbrennungsmotor” [Charge Exchange in the Internal Combustion Engine] in October. These will be followed by the "Heavy Duty" conference in November, the meeting place for all those developers who describe even a V12 commercial vehicle engine as "dinky". The season is rounded off by "Reibungsminimierung im Antriebsstrang” [Friction Minimisation in the Powertrain] at the end of November.

As you can see, we weren't exaggerating 2013 will be tightly packed with interesting conferences. In combination with our specialist media ATZ, MTZ, ATZelektronik, ATZoffhighway, MTZindustrial and Lightweight Design, we will do our best to offer you comprehensive information and to support you in your personal networking. We would be delighted to welcome you to one of these events and to have the opportunity to discuss the latest issues with you. On behalf of the entire editorial team, I wish you a happy and successful 2013.

Best regards,

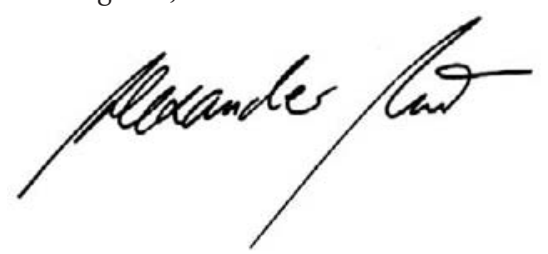

DR. ALEXANDER HEINTZEL, Editor in Chief Wiesbaden, 4 December 2012

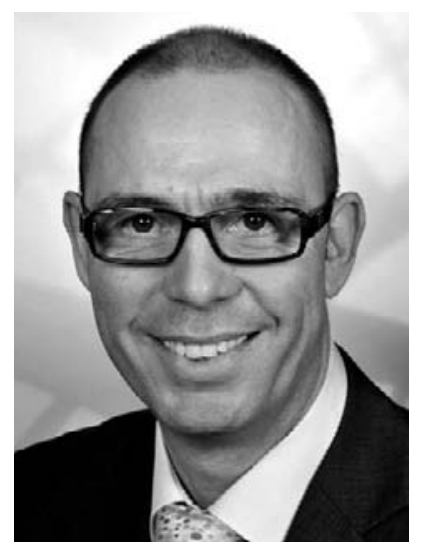

